\title{
Analisis kemampuan pemecahan masalah matematika siswa kelas IX SMP ditinjau dari gender
}

\section{Nopia Rizki¹, Sudi Prayitno², Nurul Hikmah², Muhammad Turmuzi ${ }^{2}$}

${ }^{1}$ Mahasiswa Prodi Pendidikan Matematika, FKIP Universitas Mataram

${ }^{2}$ Dosen Prodi Pendidikan Matematika, FKIP Universitas Mataram

Email: nopiarizki97@gmail.com

Diterima:20-09-2021; Direvisi:26-09-2021; Dipublikasi:30-09-2021

\begin{abstract}
The aim of this study was to describe the differences of students' problem-solving abilities in completing mathematics problem in the form of story-based problems in terms of gender difference. The type of research used is qualitative and quantitative descriptive research using research instruments, namely tests of problem-solving abilities and interview. Selection of subjects using a random cluster random technique, based on teacher considerations. The subjects in this study were 26 students of class IX in the academic year of 2020/2021. The data collection method started from making observations at school, then distributing the problem-solving ability test which contains 2 problems in the form of elaborative questions. AT the last stage, the researcher conducted interviews with 6 people who were obtained from each representative of the criteria for the test results of the problem-solving abilities that had been given. The data analysis technique in this study was conducted by looking at the test scores of mathematics problem-solving abilities seen from the criteria of high, moderate, and low. The results obtained were: (1) the ability of female students in grade IX to solve mathematics problems related to the statistical topic in form of story-based problems was in moderate criteria with the average score obtained was 73.44 , (2) the ability of male students in grade IX to solve mathematics problems related to the statistical topic in form of story-based problems was in moderate criteria with the average score obtained was 77,64, and (3) the difference in problem-solving abilities of male and female students lies on the steps used in solving mathematics problems based on Polya problem solving stages
\end{abstract}

Keywords: story-based problems, gender, polya, statistics

\begin{abstract}
Abstrak
Penelitian ini bertujuan untuk mendeskripsikan perbedaan kemampuan pemecahan masalah matematika siswa yang berbentuk soal cerita ditinjau dari perbedaan gender. Jenis penelitian yang digunakan yaitu penelitian deskriptif kualitatif dan kuantitatif dengan instrumen penelitian yaitu tes kemampuan pemecahan masalah dan wawancara. Pemilihan subjek menggunakan teknik cluster random acak, berdasarkan pertimbangan guru. Subjek dalam penelitian ini adalah siswa kelas IX ajaran 2020/2021 yang berjumlah 26 siswa. Metode pengumpulan data dimulai dari peneliti melakukan observasi ke sekolah, lalu dibagikan tes kemampuan pemecahan masalah yang berisikan 2 masalah dalam bentuk soal uraian, tahap terakhir peneliti melakukan wawancara kepada 6 orang yang diperoleh dar masing-masing perwakilan perkriteria hasil tes kemampuan pemecahan masalah yang telah diberikan. Teknik analisis data dalam penelitian ini dengan melihat nilai tes kemampuan pemecahan masalah matematika dilihat dari kriteria tinggi, sedang, dan rendah. Hasil penelitian diperoleh, (1) kemampuan pemecahan masalah matematika siswa perempuan kelas IX dalam menyelesaikan soal cerita materi statistika berada pada kriteria sedang dengan nilai rata-rata yang diperoleh adalah 73,44, dan (2) kemampuan pemecahan masalah matematika siswa laki-laki kelas IX dalam menyelesaikan soal cerita materi statistika berada pada kriteria sedang dengan nilai rata-rata yang diperoleh adalah 77,64, dan (3) perbedaan kemampuan pemecahan masalah siswa laki-laki dan perempuan terletak dari langkah-langkah yang digunakan dalam menyelesaikan masalah matematika berdasarkan tahap pemecahan masalah matematika Polya.
\end{abstract}

Kata Kunci: kemampuan pemecahan masalah, soal cerita, gender, polya, statistika 


\section{PENDAHULUAN}

Matematika merupakan mata pelajaran yang cukup penting, baik dalam perkembangan ilmu pengetahuan dan teknologi maupun dalam kehidupan sehari-hari. Dalam mempelajari matematika salah satu kemampuan yang harus dimiliki oleh siswa yaitu kemampuan pemecahan masalah. Pemecahan masalah merupakan suatu usaha untuk mencapai tujuan yang diinginkan dan tidak secara otomatis diketahui cara yang tepat untuk tujuan tersebut (Nitko, 2011). Salah satu bentuk permasalahan yang dapat digunakan dalam kegiatan pemecahan masalah matematika siswa adalah dengan memberikan soal-soal non rutin seperti soal cerita. Hal ini senada dengan pernyataan Subaidah (2010: 13) yang mengatakan bahwa salah satu cara untuk melatih kemampuan siswa dalam pemecahan masalah adalah dengan diberikannya soal cerita yang dimaksudkan untuk memperkenalkan siswa tentang kegunaan matematika dalam kehidupan sehari-hari.

Hasil analisis yang dilakukan oleh Programing for International Student Assessment (PISA) membuktikan bahwa kemampuan pemecahan masalah di Indonesia masih rendah. Sementara itu, hasil PISA pada tahun 2018 yaitu skor matematika siswa Indonesia adalah 379 dan berada pada posisi 74 dari 79 negara peserta (OECD, 2019: 17-18). Nilai ini mengalami penurunan dibanding tes di tahun 2015, di mana skor matematika siswa Indonesia adalah 386 dan berada pada posisi 63 dari 70 negara peserta. Soal-soal matematika dalam studi PISA lebih banyak mengukur kemampuan penalaran, pemecahan masalah, dan beragumentasi. Lebih dari setengah siswa Indonesia yaitu $75,7 \%$ memilki kinerja rendah dan hanya mampu menyelesaikan soal yang paling sederhana dimana konteksnya masih bersifat umum. Hanya $0,1 \%$ yang mampu mengembangkan dan mengerjakan permodelan matematika yang menuntut keterampilan berpikir dan pemecahan masalah (Nur dan Paloba, 2018).

Menurut National Council of Teacher of Mathematics atau NCTM (2000: 29) menetapkan lima standar kemampuan matematis yang harus dimiliki oleh siswa, yaitu kemampuan pemecahan masalah (problem solving), kemampuan pemahaman dan pembuktian (reasoning and proof), kemampuan komunikasi (communication), kemampuan koneksi (connections) dan kemampuan representasi (representation). Sumarmo menyatakan bahwa kemampuan-kemampuan tersebut merupakan daya matematika (mathematical power) atau keterampilan matematika (doing math). Salah satu doing math yang erat kaitannya dengan matematika adalah pemecahan masalah (problem solving) (Fauziah, 2010).

Dari hasil survei di atas, terlihat bahwa kemampuan pemecahan masalah matematika siswa di Indonesia masih membutuhkan pembenahan dan perhatian khusus. Hasil wawancara yang dilakukan tanggal 10 Agustus 2020 dengan salah satu guru matematika dikatakan bahwa kemampuan pemecahan masalah matematika masih tergolong sedang. Hal itu disebabkan oleh para siswa yang kurang memahami konsep atau materi pelajaran sehingga pada saat proses pemecahan masalah matematika siswa mendapatkan hambatan-hambatan yang berakibat pada kesalahan-kesalahan dalam proses penyelesaiannya. Dijelaskan juga bahwa dalam pembelajaran matematika partisipasi siswa perempuan lebih dominan daripada siswa laki-laki. 
Kemampuan pemecahan masalah matematika antara laki-laki dan perempuan memiliki perbedaan, perbedaannya terletak dari bagaimana cara siswa laki-laki dan siswa perempuan dalam menyelesaikan soal, sehingga terjadi kesenjangan antara tingkat partisipasi laki-laki dan perempuan. Perbedaan gender tentu menyebabkan perbedaan fisiologi dan mempengaruhi perbedaan psikologis dalam belajar, sehingga siswa laki-laki dan perempuan tentu memiliki banyak perbedaan dalam mempelajari matematika (Aminah \& Kurniawati, 2018).

Pada umumnya soal pemecahan masalah disajikan dalam bentuk soal cerita yang bersifat kontekstual, yaitu dimana soal tersebut berdasarkan pada kehidupan nyata siswa. Hal ini sesuai dengan pendapat Zulkardi dan Ilma (2006) bahwa soal kontekstual matematika merupakan soal-soal matematika yang menggunakan berbagai konteks sehingga menghadirkan situasi yang pernah dialami secara real bagi anak, konteks dapat diartikan dengan situasi, fenomena atau kejadian alam yang terkait dengan konsep matematika yang sedang dipelajari.

Dalam menyelesaikan soal pemecahan masalah matematik, tentunya kemampuan setiap anak atau individu berbeda-beda khususnya apabila dilihat dari jenis kelamin individu yaitu laki-laki dan perempuan. Dimana dasar kemampuan laki-laki itu pada penalaran dan perempuan pada ketelitian dan kecermatan dalam melakukan penyelesaian soal (Anggraeni dan Herdiman, 2018). Hal ini sesuai dengan pendapat Krutetski (Sugiyanti, 2017) yang menyatakan bahwa laki-laki lebih unggul dalam hal penalaran serta memiliki kemampuan matematika dan mekanika yang lebih baik walaupun perbedaan ini hanya tampak jelas pada tingkat yang lebih tinggi. Sedangkan perempuan lebih unggul dalam ketepatan, ketelitian, kecermatan dan keseksamaan berpikir.

Jika prestasi belajar siswa yang terintegrasi dengan kemampuan pemecahan masalah dikaitkan dengan perspektif gender, dapat ditemukan bahwa siswa laki-laki lebih memiliki ketertarikan dan rasa ingin tahu yang besar terhadap masalah, dan memiliki jalan penyelesaian masalah yang lebih variatif daripada siswa perempuan. Kepedulian siswa laki-laki dalam menyelesaikan masalah tersebut lebih rendah daripada siswa perempuan yang cenderung memberikan upaya lebih terhadap penyelesaian masalah, sehingga sering ditemukan siswa laki-laki bermalas-malasan di dalam kelas ketika proses pembelajaran (Ahmad, 2017).

Berdasarkan hasil observasi yang telah dilakukan, sebagian siswa masih mengalami kesulitan pada saat menyelesaikan soal matematika. Hal tersebut dapat dilihat pada hasil ulangan tengah semester dimana masih ada siswa yang mendapatkan nilai kurang dari nilai Kriteria Ketuntasan Minimal (KKM) yang ditentukan yaitu 75 .

\section{METODE PENELITIAN}

Jenis penelitian yang digunakan dalam penelitian ini adalah penelitian deskriptif kualitatif dan kuantitatif. Adapun yang menjadi subjek dari penelitian ini adalah 26 siswa. Waktu penelitian ini dilaksanakan pada bulan November 2020. Data yang digunakan dalam penelitian ini adalah data primer, yaitu data yang diperoleh langsung dari subjek penelitian. Adapun teknik pengumpulan datanya yaitu tes kemampuan pemecahan masalah matematika dan wawancara. Pedoman wawancara digunakan kepada subjek penelitian setelah menyelesaikan soal tes kemampuan pemecahan 
masalah yang diberikan. Tes kemampuan pemecahan masalah terdiri dari 2 soa berupa uraian materi statistika. Setelah tes dilaksanakan, selanjutnya dilakukan analisis data berdasarkan rubrik kemampuan pemecahan masalah matematika siswa. Adapun rubrik penilaian kemampuan pemecahan masalah matematika siswa dimodifikasi dari Ariani (2017) dapat dilihat pada tabel 1.

Tabel 1. Rubrik Penilaian Kemampuan Pemecahan Masalah

\begin{tabular}{|c|c|c|c|}
\hline No & $\begin{array}{c}\text { Tahap Pemecahan } \\
\text { Masalah }\end{array}$ & Deskripsi & Skor \\
\hline \multirow[t]{4}{*}{1} & $\begin{array}{lr}\text { Memahami } & \text { masalah } \\
\text { (understand } & \text { the } \\
\text { problem) } & \end{array}$ & $\begin{array}{l}\text { Menuliskan dengan benar apa } \\
\text { yang diketahui dan apa yang } \\
\text { ditanyakan pada soal }\end{array}$ & 3 \\
\hline & & $\begin{array}{l}\text { Menuliskan apa yang diketahui } \\
\text { dan apa yang ditanyakan pada } \\
\text { soal, tetapi kurang tepat }\end{array}$ & 2 \\
\hline & & $\begin{array}{l}\text { Menuliskan apa yang diketahui } \\
\text { dan/atau apa yang ditanyakan } \\
\text { pada soal tetapi kurang tepat }\end{array}$ & 1 \\
\hline & & $\begin{array}{l}\text { Tidak menuliskan apa yang } \\
\text { diketahui dan apa yang } \\
\text { ditanyakan }\end{array}$ & 0 \\
\hline \multirow[t]{4}{*}{2} & $\begin{array}{l}\text { Membuat rencana } \\
\text { (deviese a plan) }\end{array}$ & $\begin{array}{l}\text { Merencanakan penyelesaian } \\
\text { masalah dengan menuliskan } \\
\text { aturan matematika (rumus) } \\
\text { dengan benar dan lengkap } \\
\text { sehingga mengarah ke jawaban } \\
\text { yang benar }\end{array}$ & 3 \\
\hline & & $\begin{array}{l}\text { Merencanakan penyelesaian } \\
\text { masalah dengan menuliskan } \\
\text { aturan matematika (rumus) } \\
\text { dengan benar tetapi tidak } \\
\text { lengkap atau kurang tepat } \\
\text { sehingga mengarah kejawaban } \\
\text { yang salah }\end{array}$ & 2 \\
\hline & & $\begin{array}{l}\text { Salah menuliskan } \\
\text { matematika (rumus) } \\
\text { digunakan }\end{array}$ & 1 \\
\hline & & 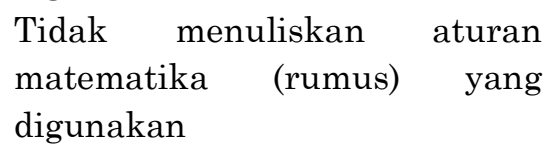 & 0 \\
\hline \multirow[t]{2}{*}{3} & $\begin{array}{l}\text { Melaksanakan rencana } \\
\text { (carry out the plan) }\end{array}$ & $\begin{array}{l}\text { Menyelesaikan dengan prosedur } \\
\text { yang benar dan sesuai dengan } \\
\text { rencana yang telah dibuat, } \\
\text { melakukan perhitungan dengan } \\
\text { benar. }\end{array}$ & 4 \\
\hline & & $\begin{array}{l}\text { Menyelesaikan dengan prosedur } \\
\text { yang benar dan sesuai dengan } \\
\text { rencana yang telah dibuat akan }\end{array}$ & 3 \\
\hline
\end{tabular}




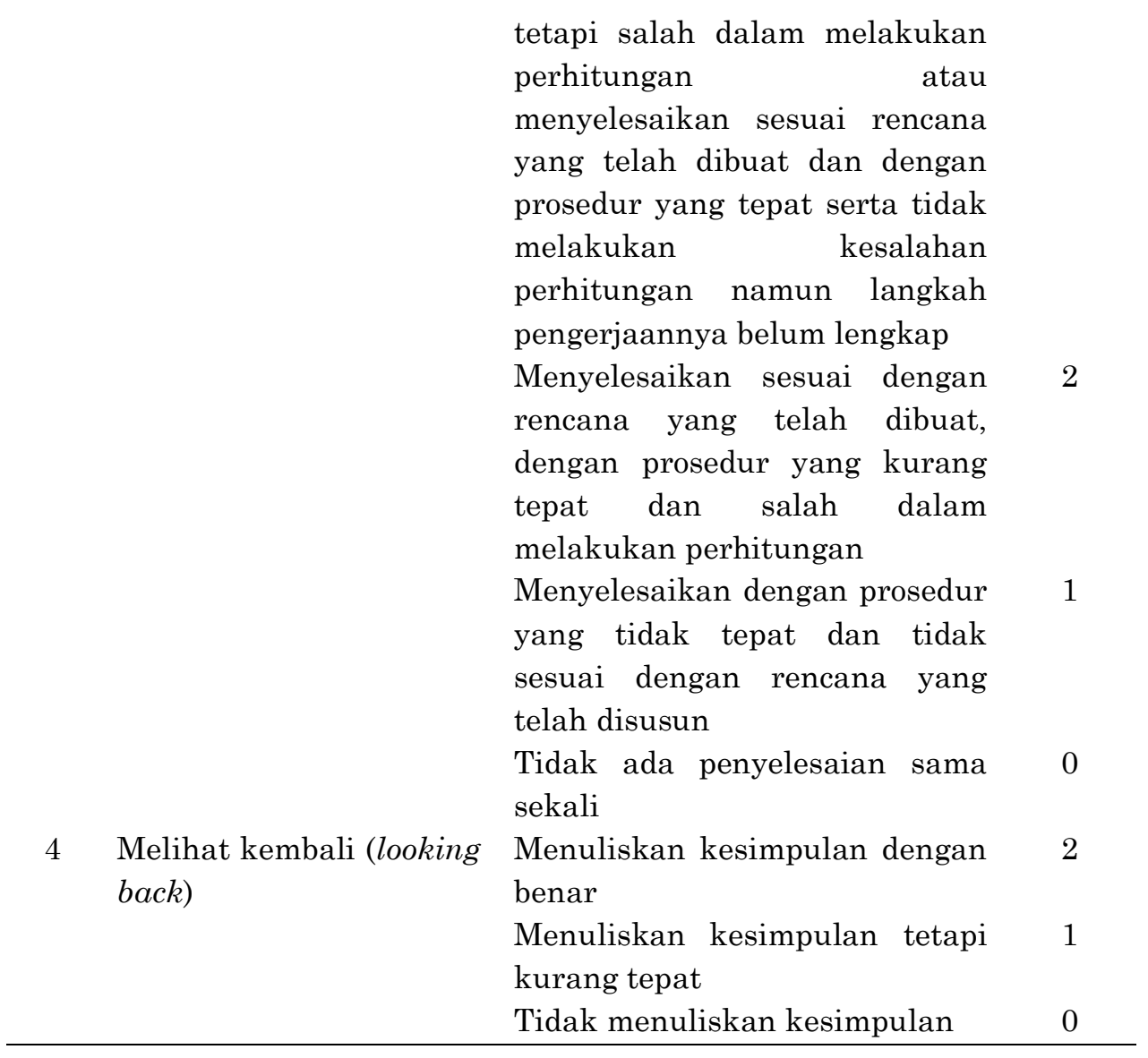

Interpretasi kemampuan pemecahan masalah yang diadopsi dari pedoman penilain berdasarkan Devita dan Pujiastuti (2020: 113). Kriteria tersebut dapat dilihat pada tabel 2.

Tabel 2. Kriteria Kemampuan Pemecahan Masalah Matematika

\begin{tabular}{c|c}
\hline Rata-rata & Kriteria \\
\hline nilai $<60$ & Rendah \\
$60,0 \leq$ nilai $<80$ & Sedang \\
$80 \leq$ nilai $\leq 100$ & Tinggi \\
\hline
\end{tabular}

Alur langkah penelitian harus disajikan dalam bagian ini lengkap dengan keterangan. Keterangan gambar yang ditempatkan sebagai bagian dari judul gambar (keterangan gambar) bukan bagian dari gambar. 


\section{HASIL DAN PEMBAHASAN}

\subsection{Hasil Validasi Instrumen}

Instrumen penelitian yang berupa tes (soal) diuji validitas terlebih dahulu sebelum digunakan untuk pengambilan data. Pengujian instrumen yang digunakan adalah pengujian validitas isi yang dikonsultasikan dengan ahli. Jumlah tenaga ahli yang digunakan adalah 5 orang. Ahli yang dimaksudkan adalah 2 dosen program studi Pendidikan matematika dan 3 guru mata pelajaran matematika. Instrumen yang akan diuji adalah instrumen yang dirancang sendiri oleh peneliti dengan menyesuaikan kompetensi dasar dan indikator pada materi statistika.

\subsection{Deskripsi Kemampuan Pemecahan Masalah Ditinjau dari Perbedaan Gender}

Kemampuan pemecahan masalah matematika siswa dapat dilihat dari nilai yang diperoleh siswa laki-laki dan siswa perempuan. Nilai tertinggi yang diperoleh siswa laki-laki yaitu 95,83 dan nilai terendahnya yaitu 0, sedangkan siswa perempuan nilai tertingginya yaitu 100 dan nilai terendahnya yaitu 45,83. Sehingga kriteria kemampuan pemecahan masalah matematika siswa berdasarkan perbedaan gender dapat dilihat pada Tabel 3.

Tabel 3. Distribusi Kemampuan Pemecahan Masalah Matematika Berdasarkan

\begin{tabular}{ccl}
\multicolumn{2}{c}{ Kriteria dari Gender } & \\
\hline Gender & Nilai Rata-rata & Kriteria \\
\hline Laki-laki & 77,64 & Sedang \\
\hline Perempuan & 73,44 & Sedang \\
\hline
\end{tabular}

Dari Tabel 3 menunjukkan bahwa persentase kemampuan pemecahan masalah matematika siswa laki-laki pada kriteria tinggi lebih besar dari siswa perempuan, pada kriteria sedang persentase kemampuan pemecahan masalah matematika siswa lakilaki lebih kecil dari siswa perempuan. Pada kriteria rendah persentase kemampuan pemecahan masalah matematika siswa laki-laki lebih kecil dari siswa perempuan.

\subsection{Analisis Kemampuan Pemecahan Masalah Matematika Siswa Ditinjau dari Perbedaan Gender Berdasarkan Teori Polya}

Berdasarkan hasil jawaban soal tes yang telah dikerjakan siswa kelas IX SMPN 8 Mataram dalam manyelesaikan soal cerita materi statistika didapatkan skor rata-rata seperti yang terlihat pada Tabel 4 .

Tabel 4. Skor Rata-rata Kemampuan Pemecahan Masalah Matematika Siswa Berdasarkan Teori Polya

\begin{tabular}{|c|c|c|c|c|c|c|c|c|c|c|}
\hline \multirow[b]{2}{*}{ Indikator } & \multicolumn{3}{|c|}{$\mathrm{L}$} & \multicolumn{2}{|l|}{ Skor } & \multicolumn{3}{|c|}{$\mathrm{P}$} & \multicolumn{2}{|l|}{ Skor } \\
\hline & $\mathrm{T}$ & $\mathrm{S}$ & $\mathrm{R}$ & $\begin{array}{c}\text { Rata- } \\
\text { rata }\end{array}$ & Kriteria & $\mathrm{T}$ & $\mathrm{S}$ & $\mathrm{R}$ & $\begin{array}{c}\text { Rata- } \\
\text { rata }\end{array}$ & Kriteria \\
\hline $\begin{array}{l}\text { Memahami } \\
\text { masalah }\end{array}$ & 10 & 5 & - & 77,78 & Sedang & 8 & 2 & - & 85 & Tinggi \\
\hline $\begin{array}{l}\text { Merencanakan } \\
\text { penyelesaian }\end{array}$ & 11 & 1 & 3 & 83,33 & Tinggi & 7 & 1 & 2 & 85 & Tinggi \\
\hline $\begin{array}{l}\text { Melaksanakan } \\
\text { penyelesaian }\end{array}$ & 4 & 5 & 6 & 60,83 & Sedang & 2 & 6 & 2 & 75 & Sedang \\
\hline Memeriksa & 8 & 6 & 1 & 86,67 & Tinggi & 3 & 3 & 4 & 57,5 & Rendah \\
\hline
\end{tabular}


Dari Tabel 4 menunjukkan bahwa skor rata-rata untuk tahap memahami masalah siswa laki-laki yaitu 77,78 dengan kriteria sedang dan skor rata-rata siswa perempuan yaitu 85 dengan kriteria tinggi. Tahap merencanakan penyelesaian skor rata-rata siswa laki-laki 83,33 dengan kriteria tinggi dan skor rata-rata siswa perempuan 85 dengan kriteria tinggi. Tahap melaksanakan penyelesaian skor rata-rata siswa laki-laki 60,83 dengan kriteria sedang dan skor rata-rata siswa perempuan 75 dengan kriteria sedang. Tahap memeriksa kembali skor rata-rata siswa laki-laki 86,67 dengan kriteria tinggi dan skor rata-rata siswa perempuan 57,5 dengan kriteria rendah.

\section{PEMBAHASAN}

\subsection{Kemampuan Pemecahan Masalah Matematika Tinggi}

Kemampuan pemecahan masalah siswa dengan kategori tinggi, tidak mengalami banyak kesulitan dalam menyelesaikan soal cerita materi statistika yang diberikan. Hal tersebut terlihat dari hasil pengerjaan siswa, siswa laki-laki dengan kemampuan pemecahan masalah tinggi mengalami kesulitan pada tahap memahami masalah yaitu kurang lengkap menuliskan hal yang diketahui sehingga kurang teliti dalam melakukan perhitungan pada tahap melaksanakan rencana penyelesaian. Sedangkan untuk siswa perempuan pada proses pengerjaan terdapat beberapa siswa yang mengalami kendala pada tahap memahami masalah yaitu kurang lengkap dalam menuliskan hal yang diketahui dari soal.

Hal ini sesuai dengan pendapat Putri (2019) bahwa terdapat perbedaan cara berpikir antara laki-laki dan perempuan meskipun hanya perbedaan kecil. Siswanti (2016) dalam penelitiannya mengungkapkan bahwa laki-laki dan perempuan secara umum memiliki perbedaan dalam merencanakan strategi yang akan digunakan untuk memecahkan masalah serta dalam melaksanakan penyelesaian masalah sesuai dengan rencana yang sudah dibuat.

\subsection{Kemampuan Pemecahan Masalah Matematika Sedang}

Kemampuan pemecahan masalah siswa dengan kategori sedang, siswa laki-laki mengalami kendala pada setiap tahap. Pada tahap memahami masalah siswa tidak lengkap menuliskan hal yang diketahui dari soal, pada tahap membuat rencana penyelesaian beberapa ada yang tidak menulis rumus dan kurang lengkap dalam menuliskan rumus yang akan digunakan, pada tahap menjalankan rencana penyelesaian mengalami kendala yaitu salah melakukan perhitungan. Hal tersebut disebabkan karena pada tahap awal siswa laki-laki pada kriteria kemampuan pemecahan masalah matematika sedang mengalami kendala sehingga pada tahaptahap selanjutnya akan mengalami kesulitan. Sedangkan pada siswa perempuan ada beberapa yang mengalami kendala pada tahap memahami masalah yaitu kurang lengkap menuliskan hal yang diketahui dari soal, sehingga pada tahap menyusun rencana tidak menuliskan rumus dan tidak menuliskan kesimpulan dari soal yang diberikan. 
Menurut Polya, menyusun rencana dalam pemecahan masalah adalah aspek yang harus dicantumkan siswa dalam meyelesaikan pemecahan masalah. Langkah ini memuat urutan langkah penyelesaian dan pengarahan pada jawaban yang benar. Merencanakan penyelesaian masalah adalah pemahaman terhadap masalah yang menghasilkan berbagai aspek yang diperlukan dalam merencanakan penyelesaian masalah. Setiap melakukan aktivitas, agar pelaksanaannya berhasil sesuai dengan yang diharapkan, sudah seharusnya dirancang perencanaan yang melibatkan strategi, pendekatan dan metode yang sesuai untuk menyelesaikannya (Ahmad, 2017).

\subsection{Kemampuan Pemecahan Masalah Matematika Rendah}

Kemampuan pemecahan masalah siswa dengan kategori rendah, siswa laki-laki mengalami kendala pada setiap tahap. Pada tahap memahami masalah siswa tidak lengkap menuliskan hal yang diketahui dari soal, pada tahap membuat rencana penyelesaian beberapa ada yang tidak menulis rumus dan kurang lengkap dalam menuliskan rumus yang akan digunakan, pada tahap menjalankan rencana penyelesaian mengalami kendala yaitu salah melakukan perhitungan dan tidak menuliskan kesimpulan dari soal yang diberikan. Sedangkan siswa perempuan mengalami kendala pada tahap memahami masalah yaitu kurang lengkap menuliskan hal yang diketahui dari soal, pada tahap menyusun rencana siswa masih kurang tepat dalam menuliskan rumus yang akan digunakan sehingga mengakibatkan siswa salah dalam melakukan perhitungan dan tidak menuliskan kesimpulan dari soal yang diberikan.

Menurut Netriwati (2016) bahwa empat tahap pemecahan masalah dari Polya merupakan suatu kesatuan yang sangat penting untuk dikembangkan. Perbedaan gender dapat menjadi faktor pembeda dalam kemampuan pemecahan masalah matematika yang dimiliki siswa. Menurut Pellokila (2020) bahwa siswa laki-laki dan siswa perempuan memiliki strategi yang berbeda dalam menyelesaikan masalah matematika/soal cerita. Perbedaan gender mempunyai andil untuk menerangkan profil seseorang dalam menyelesaikan masalah, siswa juga tidak biasa untuk berpikir kritis, membuat dugaan-dugaan, mencoba berbagai strategi atau percobaan pendahuluan, berpikir hal-hal yang tidak rutin dan baru, serta membuat kesimpulan (Prayitno, 2013). Hal ini memperkuat dugaan bahwa perbedaan kemampuan matematika dan gender turut berpengaruh dalam berpikir untuk menyelesaikan masalah matematika (Pellokila, 2020).

\subsection{Perbedaan Kemampuan Pemecahan Masalah Matematika pada Siswa Laki-laki dan Perempuan}

Kemampuan pemecahan masalah matematika antara laki-laki dan perempuan memiliki perbedaan, perbedaannya terletak dari bagaimana cara siswa laki-laki dan siswa perempuan dalam menyelesaikan soal, sehingga terjadi kesenjangan antara tingkat partisipasi laki-laki dan perempuan (Davita \& Pujiastuti, 2020). Perbedaan gender dapat menjadi faktor pembeda seseorang berpikir dan menentukan pemecahan masalah yang diambil. Ketika dihadapkan pada soal yang berbasis pemecahan masalah, siswa laki-laki dan perempuan memiliki kecenderungan pemecahan masalah yang berbeda. 
Berdasarkan hasil penelitian, diperoleh perbedaan kemampuan pemecahan masalah matematika antara siswa laki-laki dan perempuan yaitu pada langkahlangkah yang digunakan untuk menyelesaikan masalah matematika berdasarkan tahap polya. Dimana pada penelitian ini, dalam setiap tahap proses penyelesaian masalah terlihat bahwa siswa perempuan lebih unggul dari siswa laki-laki kecuali pada tahap memeriksa kembali. Karena siswa perempuan lebih mampu menangani pemecahan masalah yang bersifat holistik, dimana siswa perempuan lebih berfokus pada proses penyelesaian masalah yang digunakan bukan pada hasil yang didapatkan. Hal ini senada dengan pendapat Colomeischia terdapat perbedaan sikap siswa laki-laki dan perempuan terhadap pembelajaran matematika. Siswa perempuan lebih mampu menangani pemecahan masalah yang bersifat holistik sedangkan siswa laki-laki lebih kuat dalam menganalisis permasalahan spesifik (Nur dan Palobo, 2018).

\section{SIMPULAN}

Berdasarkan hasil penelitian dan pembahasan yang telah dipaparkan maka dapat diambil kesimpulan sebagai berikut:

1. Kemampuan pemecahan masalah matematika siswa perempuan kelas IX dalam menyelesaikan soal cerita materi statistika berada pada kriteria sedang dengan nilai rata-rata yang diperoleh adalah 73,44 .

2. Kemampuan pemecahan masalah matematika siswa laki-laki kelas IX dalam menyelesaikan soal cerita materi statistika berada pada kriteria sedang dengan nilai rata-rata yang diperoleh adalah 77,64 .

3. Perbedaan kemampuan pemecahan masalah siswa laki-laki dan perempuan terletak dari langkah-langkah yang digunakan dalam menyelesaikan pemecahan masalah yang diberikan. Pada tahap memahami masalah, skor rata-rata yang diperoleh siswa laki-laki adalah 77,78 berada pada kriteria sedang, skor rata-rata yang diperoleh siswa perempuan adalah 85 dengan kriteria tinggi. Tahap merencanakan penyelesaian, skor rata-rata yang diperoleh siswa laki-laki adalah 83,33 berada pada kriteria tinggi, skor rata-rata yang diperoleh siswa perempuan adalah 85 dengan kriteria tinggi. Tahap melaksanakan penyelesaian, skor rata-rata yang diperoleh siswa laki-laki adalah 60,83 berada pada kriteria sedang, skor ratarata yang diperoleh siswa perempuan adalah 75 dengan kriteria sedang. Tahap memeriksa kembali, skor rata-rata yang diperoleh siswa laki-laki adalah 86,67 berada pada kriteria tinggi, skor rata-rata yang diperoleh siswa perempuan adalah 57,5 dengan kriteria rendah.

\section{REFERENSI}

Ahmad, A. M. 2017. Aspek Merencanakan Pemecahan Masalah Geometri Ditinjau dari Pendekatan Polya Berdasarkan Gender. Prosiding S1 MaNIs (Seminar Nasional Integrasi Matematika dan Nilai Islami), 1(1): 319-326.

Anggraeni, R dan Herdiman, I. 2018. Kemampuan Pemecahan Masalah Matematik Siswa SMP Pada Materi Lingkaran Berbentuk Soal Kontekstual Ditinjau dari Gender. Jurnal Numeracy, 5(1): 19-28.

Ariani, S., Hartono, Y., dan Hiltrimartin, C. 2017. Kemampuan Pemecahan Masalah Matematika Siswa pada Pembelajaran Matematika Menggunakan Strategi 
Abduktif-Deduktif di SMA Negeri 1 Indralaya Utara. Jurnal Glemen, 3(1): 2534.

Davita, P. W. C. dan Pujiastuti. 2020. Analisis Kemampuan Pemecahan Masalah Ditinjau dari Gender. Jurnal Matematika Kreatif-Inovatif, 11(1): 110-117.

Fauziah, A. 2010. Peningkatan Kemampuan Pemahaman dan Pemecahan Masalah Matematika Siswa SMP Melalui Strategi REACT. Forum Pendidikan, 30(1): 113.

National Council of Teacher Mathematics (NCTM). 2000. Principle and Standards for School Mathematics. Reston: NCTM.

Netriwati. 2016. Analisis Kemampuan Pemecahan Masalah Matematika Berdasarkan Teori Polya Ditinjau dari Pengetahuan Awal Mahasiswa IAIN Raden Intan Lampung. Jurnal Pendidikan Matematika, 7(2): 181-190.

Nitko, A. J. 2011. Educational Assessment of Student. Englewood Cliffs. NJ: Merrill Prentice Hall, Inc.

Nur, A. S. dan Pabolo, M. 2018. Profil Kemampuan Pemecahan Masalah Matematika Siswa Ditinjau dari Perbedaan Gaya Kognitif dan Gender. Jurnal Matematika Kreatif-Inovatif, 9(2), 139-148.

OECD. 2019. PISA 2018 Results: What Students Know and Can Do - Student Performance in Mathematics, Reading and Science Volume I. PISA: OECD Publishing.

Prayitno, S, Suwarsono, St., dan Siswono, T. Y. E. 2013. Komunikasi Matematis Siswa SMP dalam Menyelesaikan Soal Matematika Berjenjang Ditinjau dari Perbedaan Gender. Prosiding Seminar Nasional Matematika dan Pendidikan Matematika, Yogyakarta: 9 November 2013-ISBN: 978-979-16353-9-4: 566-572.

Putri, F. F. W. 2019. Profil Kemampuan Penalaran Siswa SMP Dalam Menyelesaikan Masalah Matematika Ditinjau dari Tipe Kepribadian dan Jenis Kelamin. Jurnal Ilmiah Pendidikan Matematika, 8(1): 38-45.

Siswanti, R. E. 2016. Penalaran Siswa Dalam Memecahkan Masalah Matematika Ditinjau dari Perbedaan Jenis Kelamin. Jurnal Ilmiah Pendidikan Matematika, 2(5): 90-99.

Subaidah. 2010. Analisis Kesalahan Siswa Dalam Menyelesaikan Soal Bentuk Aljabar Kelas VII SMP. Jurnal Matematika UMY, 1(1): 1-19.

Sugiyanti, S. 2017. Analisis Kemampuan Pemecahan Mawalah pada Materi Bangun Ruang Sisi Lengkung Berbentuk Soal Cerita Ditinjau dari Gender. Artikel Skripsi Universitas Nusantara PGRI Kediri.

Zulkardi dan Ilma, R. 2006. Mendesain Sendiri Soal Kontekstual Matematika. Prosiding KNM13. Semarang. 